Vol. 56, z. 1-2 - 2003

s. $21-25$

\title{
Prediction of viability of leek (Allium porrum) seeds by a new test
}

\author{
I. GÜVENÇ, H. C. KAYMAK \\ Department of Horticulture, College of Agriculture, Atatürk University, \\ 25240 Erzurum. Turkey.
}

(Received: 2. 10. 2002)

\section{Summary}

The objective of this research was to determine the suitability of boiling water test in the prediction of seed viability in leek seed and to compare this test with standard germination and vigour test. Basic principle of boiling water test is the evaluation of radicle protrusion from the seeds immersed to boiling water for certain time. The viability of aged and unaged leek seeds in boiling water test was correlated with standard germination and vigour test. In this research, the mean germination of unaged leek seeds varied from $29,63 \%$ to $70,18 \%$ depending on the cultivars. While the range of boiling water test in unaged leek seeds was between $35,57 \%$ to $51,06 \%$, the range for emergence was between $27,63 \%$ to $72,05 \%$. The viability of aged and unaged leek seeds in boiling water test was correlated with standard germination test. According to the results of this research, it might be assessed that boiling water test is a rapid and simple method to measure seed viability by evaluating radicle protrusion of leek seeds in boiling water. In conclusion, boiling water test as a new viability test for leek seed could be used as a rapid method for determining the viability in leek seeds.

Key words: Leek (Allium porrum), seed viability

\section{INTRODUCTION}

Numerous tests exist for determining seed viability and vigour in vegetable crops. Viability means that a seed is capable of germinating and producing a normal seedling (Copeland, Mc Donald, 1985). Generally, the standard germination test is accepted as the primary method for determining seed quality. When field conditions at planting are near optimum, standard germination tests correlate well with field emergence ( Hall. Wiesner, 1990). Regardless of its acceptance, the germination test is merely an estimate and has certain limitations as a universal prediction of seed quality. However, a quick test might be completed only in a few hours as compared to some germination tests that may require as long as two months for some species (Copeland, Mc Donald, 1985). 
All of the viability tests conducted to determine seed viability require a certain period of time. According to the ISTA rules, the standard germination test for leek seeds is completed within 14 days. Therefore, sometime it is essential to determine rapidly seed viability. Some researchers reported that boiling water test can be provided as a rapid indicator of onion seed viability in seed lots instead of other timeconsuming germination tests ( $\mathrm{G}$ ü ven ç, 2002). However, the usefulness of the boiling water test in a case of leek seeds has not been clearly identified. Therefore, the objective of this research was to determine the suitability of the boiling water test in the prediction of leek seed viability and vigour, and to compare this test with the standard germination test.

\section{MATERIAL AND METHODS}

This study was conducted at Atatürk University, College of Agriculture, Erzurum, Turkey, during years 2001-2002. In this study, four leek (Allium porrum) cultivars (Ala, Uzun-Beyaz, Kalem and Inegöl-92) seeds were used as plant material. Seeds of 7 lots (Ala, Uzun-Beyaz, Kalem and Inegöl-92a, b, c and d) from 4 cultivar of leek were supplied by vegetables seed companies in Turkey.

The seeds were separated into 1-2 mm size grades using a range of round holed sieves with holes of diameter 1:2 mm. Besides, weight of seeds was calculated from the weight of three replications of 100 air-dried seeds.

The seeds of all leek cultivars were divided into two parts, and while one part of seeds was subjected to accelerated aging to lower quality prior to viability tests, the others had not any treatment. Thus, untreated seeds were used as unaged seeds. Artificially accelerated aged seeds were conducted as recommended by some researchers (Hall, Wiesner, 1990) with minor procedural modifications. The seeds of leek cultivars were distributed evenly on wire mesh trays inside a closed container with water at the bottom and placed in an aging chamber (a oven) for 4 days (Co pel and, Mc Donald, 1985). During the accelerated aging, temperature and relative humidity were maintained at $41^{\circ} \mathrm{C}$ and $95 \%$, respectively. Following the aging period, the seeds were removed, and boiling water, standard germination and emergence tests were applied to the aged and unaged (untreated) seeds.

Boiling Water Test (BWT): Principle of BWT is based on the evaluation of radicle protrusion from the seeds immersed into boiling water for certain time ( $\mathrm{G}$ ü ve n ç, 2002). Leek seeds from each cultivars were immersed into boiling water in a glass container (a beaker), and they were monitored for the protrusion with 10 minutes intervals during the boiling up to 60 minutes. During the boiling, the number of protruded seeds were counted and removed. Seeds, which had protruded radicles was recorded as viable. In this test, the viability was defined as the emergence of radicle through the seed coat during the boiling process. The boiling water test was conducted using four replicates of 50 seeds per a leek cultivar or lot.

Standard germination tests (SGT): Standard germination tests were conducted using four replicates of 50 seeds from each seed cultivar or lot. The seeds were incuba- 
ted in $9 \mathrm{~cm}$ Petri dishes between two filter papers saturated with water containing Benlate $1 \mathrm{~g} / \mathrm{l}$ to prevent fungal growth at $20^{\circ} \mathrm{C}$ ( $\mathrm{K}$ an tar, Güvenç, 1995). Visible radicle protrusion was the criterion of germination. Germinate $\mathrm{d}$ seeds were recorded and discarded at $24 \mathrm{~h}$ intervals during 14 days (ISTA 1996). The results were expressed as final germination percentage.

Emergence Trial (ET ): Again 4 times 100 seeds of leek cultivars used in this research were sown at $1 \mathrm{~cm}$ depth of loamy soils in rows. Emergence percentages of the seeds were calculated for the cultivars.

Statistical analyses: Laboratory experiments were conducted as randomized complete block designs, with each treatment replicated four times. Percentage data were transformed using arcsine (\% 0.05) prior to statistical analysis. The data obtained in this study were subjected to ANOVA and the differences between means were compared using LSD test. Besides, correlation coefficients (r) and regression relation were determined between the tests conducted.

\section{RESULTS AND DISCUSSION}

The data for the results of different tests on viability of the leek seeds is presented in Table 1. The mean value of viability of aged and unaged seeds of leek varied depending on the cultivars and test method. While the range of germination test results in unaged seeds was between $29,63 \%$ (Inegöl-92d) to 70,18\% (Inegöl-29b) , the range for boiling water test was between $35,57 \%$ (Inegöl-92c) to 51,06\% (Inegöl$92 \mathrm{~b})$. The viability of unaged leek seeds in the boiling water test was correlated with standard germination and vigour test (Table 2). Germination percentage in aged seeds were the lowest with Inegöl-92d (4.93\%) and the highest with Kalem (34,76\%). Besides, the highest viability values for the boiling water test in aged seeds of leek was obtained from Inegöl-92a (31,92\%).

Table 2. Simple correlation coefficients ( $r$ ) between viability and emergence test

\begin{tabular}{|c|c|c|c|c|c|c|}
\hline & \multicolumn{3}{|c|}{ Unaged Seeds } & \multicolumn{3}{|c|}{ Aged Seeds } \\
\hline & $\begin{array}{l}\text { Germination } \\
\text { (1) }\end{array}$ & $\begin{array}{l}\text { BWT } \\
(2)\end{array}$ & $\begin{array}{l}\text { Emergence } \\
\text { (3) }\end{array}$ & $\begin{array}{c}\text { Germination } \\
\text { (4) }\end{array}$ & $\begin{array}{l}\text { BWT } \\
(5)\end{array}$ & $\begin{array}{l}\text { Emergence } \\
\text { (6) }\end{array}$ \\
\hline Seed Weight & NS & NS & NS & NS & $-0.448^{*}$ & $-0,510^{*}$ \\
\hline U.Germin. (1) & & $0.532^{\circ}$ & $0.952^{\ldots-1}$ & $0.566^{\circ}$ & 0.751 **** & NS \\
\hline U.BWT (2) & & - & $0.510^{\circ}$ & NS & NS & NS \\
\hline A.Germin.(4) & & & & - & $0.514^{\circ}$ & $0.651^{\circ}$ \\
\hline A.BWT( (5) & & & & - & - & $0,505^{\circ}$ \\
\hline
\end{tabular}

(*): Significant $\mathrm{P}<0,01$ Level. (**): Significant $\mathrm{P}<0,05$ level (NS): not significant $\mathrm{U}$-unaged, A-aged 
Generally, the predicted viability values for aged and unaged leek seeds in the boiling water test were lower than those of the standard germination (Table 1). These differences might be attributed to differences in test method and viability levels of seeds. The poor seed vigour naturally present in some lots could have been due to improper harvesting and handling, poor storage conditions and some other factors reducing the seed quality (Waters, Blanchette, 1983). The viability of leek seeds determined with the boiling water test in accelerated aging applied or unapplied seeds had significantly positive correlation with the standard germination test (Table 1). These results agree with a similar study on onion (G ü ve nç, 2002).

Table 1. Seed viability and vigour in relation to germination and boiling water test in aged and unaged leek seeds

\begin{tabular}{|l|c|c|c|c|c|c|c|}
\hline & & \multicolumn{3}{|c|}{ Unaged Seeds } & \multicolumn{3}{c|}{ Aged Seeds } \\
\hline $\begin{array}{l}\text { Cultivar or } \\
\text { seed lot }\end{array}$ & $\begin{array}{c}\text { Seed } \\
\text { weight }(\mathrm{g})\end{array}$ & $\begin{array}{c}\text { Germination } \\
(\%)\end{array}$ & $\begin{array}{c}\text { BWT } \\
(\%)\end{array}$ & $\begin{array}{c}\text { Emergence } \\
(\%)\end{array}$ & $\begin{array}{c}\text { Germination } \\
(\%)\end{array}$ & $\begin{array}{c}\text { BWT } \\
(\%)\end{array}$ & $\begin{array}{c}\text { Emergence } \\
(\%)\end{array}$ \\
\hline Ala & 3,88 & 64,52 & 42,99 & 59,67 & 31,76 & 26,36 & 17,30 \\
\hline U-Beyaz & 3,00 & 50,47 & 40,69 & 46,43 & 24,73 & 24,46 & 28,54 \\
\hline Kalem & 3,36 & 65,27 & 44,71 & 67,81 & 34,76 & 26,33 & 33,16 \\
\hline Inegöl-92a & 2,97 & 65,27 & 49,73 & 60,33 & 21,56 & 31,92 & 18,68 \\
\hline Inegöl-92b & 3,40 & 70,18 & 51,06 & 72,05 & 20,01 & 27,55 & 11,25 \\
\hline Inegöl-92c & 2,77 & 49,89 & 35,57 & 51,06 & 29,66 & 27,83 & 27,22 \\
\hline Inegöl-92d & 3,70 & 29,63 & 41,84 & 27,63 & 4,93 & 14,65 & 1,28 \\
\hline LSD $(\%$ I) & 0,334 & 7,208 & 10,117 & 7,46 & 15,190 & 5,682 & 11,621 \\
\hline
\end{tabular}

* Boiling Water Test

According to the results of this research, it might be assessed that the boiling water test could be used as rapid and simple method to measure seed viability by evaluating radicle protrusion of leek seeds in boiling water. Furthermore, this test is easy to standardize among laboratories tests compared to standard germination test, and it does not require any special equipment and/or expertise. However, this method may need further research in prediction of the viability of leek seeds. In conclusion, boiling water test is new or novel technique to test leek viability, and it has a great potential to test germination rapidly in the leek seeds.

\section{REFERENCES}

ISTA.1996. International for Seed Testing Rules. International Seed Testing Association, Zurich, Switzerland.

Copeland L. O., M. B. Mc Donald, 1985. Principles of Seed Science and Technology (Second Edition). Macmillan Publishing Company, New York, USA, pp. 321.

H all R. D., L. E. Wiesner, 1990. Relationship between seed vigor test and field performance of Regar meadow bromegrass. Crop Science, 30 (5): 967-970.

Güvenç I., 2002. Prediction of viability of onion (Allium cepa) seeds by boiling water test. Indian J. Agric. Sci. 72: 111-2. 
Kant ar F.. Güvenç I.. 1995. Estimation of Cardinal Temperature and Thermal Time Requirements for Nationally Registered Cultivars of Phaseolus Beans. Journal of the Faculty of Agriculture 26: 285-93.

Waters L. Jr., B. L. B I a n chette. 1983. Prediction of sweet corn field emergence by conductivity and cold tests. J. Amer. Soc. Hort. Sci., 108:778-781.

\section{Ocena żywotności nasion pora (Allium porrum) nowym testem}

\section{Streszczenie}

Celem badań była ocena przydatności testu z użyciem wrzącej wody do określenia żywotności nasion pora i porównanie uzyskanych przy jego pomocy wyników w rezultatami testów standardowych zdolności kiełkowania i wigoru.

Podstawową zasadą tego testu jest ocena stopnia przebicia okrywy nasiennej przez korzonek zarodkowy u nasion umieszczonych przez określony czas we wrzącej wodzie. Żywotność nasion pora poddanych i nie poddanych sztucznemu postarzaniu była zgodna z wynikami powszechnie stosowanych testów kiełkowania i wigoru. Średni procent nasion pora nie poddanych starzeniu wahał się od 29,63 do 70,18 zależnie od odmiany, podczas gdy wyniki uzyskane przy użyciu testu wrzącej wody wahały się w granicach $35,57-51,06 \%$, a zakres wschodów roślin - w granicach $27.63-72.05 \%$. Na podstawie otrzymanych wyników można uznać test wrzącej wody jako szybką i prostą metodę. przydatną do oceny żywotności nasion pora. Polega ona na ocenie przebicia okrywy nasiennej przez korzonek zarodkowy u nasion, które umieszczono we wrzącej wodzie.

Reasumując, test we wrzącej wodzie jest nową metodą oceny żywotności nasion pora i może być wykorzystany do szybkiej oceny tej cechy. 